\title{
LANGUAGE COMPLEXITY, NARRATIVES AND THEORY OF MIND OF ROMANI SPEAKING CHILDREN
}

\author{
Hristo Kyuchukov \\ hkyuchukov@gmail.com \\ University of Silesia in Katowice, Poland \\ Jill de Villiers \\ jdevilli@email.smith.edu \\ Smith College in Northampton, USA
}

Received October 10, 2018; Revised December 24, 2018; Accepted December 28, 2018

\begin{abstract}
The paper presents research findings with 56 Roma children from Macedonia and Serbia between the ages of 3-6 years. The children's knowledge of Romani as their mother tongue was assessed with a specially designed test. The test measures the children's comprehension and production of different types of grammatical knowledge such as wh-questions, wh-complements, passive verbs, possessives, tense, aspect, the ability of the children to learn new nouns and new adjectives, and repetition of sentences. In addition, two pictured narratives about Theory of Mind were given to the children. The hypothesis of the authors was that knowled ge of the complex grammatical categories by children will help them to understand better the Theory of Mind stories. The results show that Roma children by the age of 5 know most of the grammatical categories in their mother tongue and most of them understand Theory of Mind.
\end{abstract}

Keywords: Romani, language assessment, Theory of Mind, language complexity.

Кючуков Хрісто, де Віллєрз Джіл. Мовна складність, наративи й «теорія розуму» ромських дітей.

Анотація. У статті представлено результати досліджень, проведених за участі 56 ромських дітей з Македонії та Сербії у віщі від 3 до 6 років. За допомогою спеціально розробленого тесту було оцінено знання дітьми ромської мови як рідної. Завданням тесту було визначенння рівня розуміння мови у дітей, а також їхнє володіння різними видами граматичних знань, таких як: wh - питання, wh - доповнення, пасивні дієслова, присвійний відмінок, час, граматичний аспект, здатність опановувати нові іменники та прикметники, а також повторення речень. Крім цього, діти отримали два ілюстрованих наративи про «теорію розуму». Гіпотеза авторів полягала в тому, що знання дітьми складних граматичних категорій допоможе їм краще зрозуміти розповіді про «теорію розуму». Результати довели, що ромські діти у віщі до 5 років знають більшість граматичних категорій рідної мови, і більшість 3 них розуміють сутність «теорії розуму».

Ключові слова: ромська мова, мовна оцінка, «теорія розуму», мовна складність.

\section{Introduction}

\subsection{Triple Jeopardy}

The Roma children in Europe all too often grow up in poverty, marginalization and stigma. From the point of view of the language they speak - Romani - they grow up in a kind of triple jeopardy compared to other children in the world:

(C) Kyuchukov, Hristo; de Villiers, Jill, 2018. This is an Open Access article distributed under the terms and conditions of the Creative Commons Attribution 4.0 International Licence (http://creativecommons.org/licenses/by/4.0).

East European Journal of Psycholinguistics, 5(2), 16-31. https://doi.org/10.5281/zenodo.2583166 
a) Their families are often poor and in most of the cases grow up in families where the parents are uneducated.

b) From a very young age they become multilingual, learning other dialects of Romani and/or other minority languages, but in most of the cases not learning the state language from birth.

c) They are part of a stigmatized group, a group that is often subject to discrimination in housing, employment and education (Vassilev, 2004; ERRC, 1999, 2015; Kyuchukov, 2005, 2010). Since the status of a language is perfectly predicted by the status of the people who speak it, Romani is often regarded as a deficient or degraded language.

Consider first the impact of socioeconomic status (SES) on language in the US and in West Europe, SES is blamed for the word gap (Hart \& Risley 1995), in research that has demonstrated that lower class children are exposed to 30 million fewer words spoken to them than are spoken to middle class children between 2 and 5 years. In the US this lack of exposure has been linked to poorer performance in the early grades of schooling, and a large gap in achievement in education. However, many psychologists and linguists are not convinced that the count of words is the best index of rich language exposure, it is merely a proxy for conversational attention. More recent research findings show that it is not the count of words that matter, but conversational turns, and rich conversations that acknowledge the child as a participant (Hirsh-Pasek et al., 2015).

Kyuchukov (2014) has studied the language in the home of Roma families in Eastern Europe, and draws the conclusion that their style of interaction is in fact conducive to rich language learning despite the lack of material wealth and parental education. Although the Roma families are poor and the parents are uneducated the children grow up in an emotional and loving environment, which supports their language and cognitive development. The Roma children learn Romani in a way that is not traditional for educated families in the West. The Roma culture being an oral one is rich with anecdotes, songs, lullabies, fairytales, and folkloristic language games. From a very early age the children get exposed to complex grammatical structures and different registers, because living in extended families the care of the growing child is a responsibility of the whole family and very often of the whole community. Everyone in the family (and community) is free to talk and to play with the child. In Roma culture if a neighbor speaks to your child, makes jokes, sing songs to him or her, this is considered to be a sign of respect to the family. This is not the modern West European culture and style of communication, where the children get knowledge about the world through books and conversations in a nuclear family. The young children learn from everyone: from older brothers and sisters, grandparents, cousins, neighbors.

The expectation for the young children is that by the age of 2 years they should have not only enough lexical knowledge but also they should understand more complex sentences in instructions such as "Bring me X, which is in Y". The child might be in a situation such that s/he never before saw, heard or used that word or knew about the object (Kyuchukov, 2005). The parents expect that the child will have enough knowledge of the language and enough experiences to find the object they are asked 
for, by making inferences for example about what is new, or what the parent might need to complete a task. If the child cannot find the correct object and s/he brings another one, then the parent does not continue by showing the correct object and naming it, but rather the parent will repeat the request until the moment the child by himself finds the object the parent needs. The child is given autonomy to work things out, and so learning takes place in a quite different style. All these actions of the adults towards the children in Roma communities show the expectations of the parents that their children can master the language within communicative situations from an early age. They have to get the knowledge about the surrounding world through actions, and they have to repeat the activity until they are successful, until that moment they learn the new words and start to use them. (Reger, 1999; Reger \& Berko-Gleason, 1991; Kyuchukov, 2015)

Nevertheless, differences in a style of language development do not necessarily result in the same readiness for Western schooling. Heath (1982) and others have shown that schools tend to represent the learning styles and conditions of Western middle class families, and coming to that by a different route can leave a child ill equipped to fit in the culture of school (Hoff 2013). In the famous study by Heath, lower class White and African American children were taught within their families in different ways than the middle class White families, despite all living in the same state (North Carolina) in the US. When they arrived at school, the middle class children's preparation with connecting the content of books to events in their lives, os tensive naming of objects, and "test" questions from their parents all placed them in an advantageous position with regard to school practices. That is not to say that the other groups experienced a less rich language environment, but the skills they acquired were at variance with the school's demands.

The Roma children thus face the same problems from their different style of language development when it comes to readiness for schooling as do other socioeconomically disadvantaged children from different cultures and children at risk (Merz et al., 2015; Landry et al., 2013). Even growing up in rich language circumstances, the disparities between school and parenting style reduce the probability of academic achievements of the children with low socio-economic status (Heath, 1981).

Turning to the second jeopardy, the multilingualism among the Roma children is considered to be a problem. It is widely acknowledged that learning several languages at once slows children down in mastering each language relative to a monolingual for about the first 7 years of learning (though of course there are individual differences) (Hoff \& Elledge,2005). However, when one counts the knowledge that is distributed across the languages, then bilingual children are just as linguistically competent as monolinguals (Bedore, Peña, Garcia \& Cortez, 2012). And the advantages of bilingualism are everywhere promoted. Multilingualism can help a child cognitively even before the languages reach mastery, in areas such as executive function and metalinguistic awareness in which a bilingual advantage has been found (Bialystok, 2001; Bialystok \& Craik, 2010; Carlson \& Meltzoff, 2008). Millions of dollars are spent on higher education to teach second languages to monolingual high school 
students, college students and adults so they can be functional in the modern world. Recent research has documented the protective effects of multilingualism on the aging brain, with reports of a two-year lag in the onset of senile dementia in people who speak more than one language (Bialystok, Craik \& Freedman, 2007). It is important therefore to put the Roma child's bi- or multilingualism in perspective. The child may not be as competent in each of the languages as a monolingual peer at the younger ages, but it is important that this must not be judged as a problem in the early grades. By age 8 or 9 years, bilingual children typically catch up to their monolingual peers in their languages, unless there is an additional factor that comes into play, namely, the status of their home language. When there is stigma attached, as with African American English in the US, or even Spanish in some regions of the US, then a third source of jeopardy comes into play.

Usually the Roma children speak Romani, which commonly does not have prestige in the societies in which they live. Given their socio-economic circumstances, they often speak language(s) and dialect(s) of other minority groups who also are without respect in their societies. Some European researchers even consider that the greatest problem of the Roma children is their knowledge of Romani as a mother tongue, and that is seen as an obstacle for better acquisition of the official language of the country (Bakalar, 2004). In several European countries, if the Roma children do not have mastery of the official language of the country by the age of 6 when they have to enter primary school, they are considered to be cognitively impaired and are sent to special schools (ERRC, 1999; 2015; Fremlova \& Ureche, 2011). For example, in Slovakia up to $65 \%$ of the Roma children are in special schools because of lack of knowledge of Slovak language (Lajčakova, 2013). Some of the Roma children who speak Slovak to some degree, or who know a dialect variety of Slovak, are still treated as needing special schools designed for children with serious mental handicaps (Friedman, Gallová Kriglerová, Kubánová \& Slosiarik, 2009; Kyuchukov, 2013, 2014)

The stigma against the Roma people (and therefore against their language) can be a major risk factor, just as with children who speak the stigmatized dialect of African American English in the US. That's why it is vital to make sure people do not consider differences as deficits, that educators and policy makers must acknowledge their prejudice and clear it away for fair testing. In the US, the second author has been involved in creating fair language tests for children who speak African American English, to demonstrate their competence in their home language (e.g. the DELV test: Seymour, Roeper \& de Villiers 2005). However, there are no linguistic or psychological tests in Romani. In order to reduce the prejudice and discrimination against the Roma children, a first important step would be a test of the Romani language for children. If it can be demonstrated that the children have adequate mastery of their mother tongue there is less likelihood that they will be seen as needing special education, and appropriate provision can be made for introducing them to the language of the state without denigrating their home language. This is why we have developed such a test and we are trying to answer some important questions with it. Before we describe the test, it is necessary to situate the research we report within the special circumstances in Sweden. 


\subsection{Research Questions}

How much do the children know of the Romani language by the age of 3-6 and which grammatical categories do they know? These are some of the research questions which we try to answer. However, the test we have developed is far from standardized yet. In some recent publications we have looked at how much the Roma children in Bulgaria and Slovakia know of the grammar of their mother tongue using this specially designed and developed test on language assessment. The first results on small samples ( 30 at a time, ages 3 to 6 ) show that most of the Roma children by the age of 5 perform at about the $80 \%$ level on most of the grammatical categories of their mother tongue. Not only that but they can transfer the knowledge, e.g. applying the new rules to brand new words given to them in the test (Kyuchukov, 2013; Kyuchukov \& de Villiers, 2014a, b).

Though we are encouraged by these initial results, we need ways to validate the test against other indices if the child's language competence. It is usually the case that a new language test is compared to linguistically sophisticated analyses of the spontaneous speech of the child, to ensure that it reflects the real life language the children can produce (Pearson, Jackson \& Wu, 2014). But there are hazards here too, in that some young children may be shy or timid and not speak much, and a long transcript might not contain much of anything for the linguist to analyze. More fruitful might be to use more controlled circumstances to obtain some elicited speech, and then the use of a wordless picture book is helpful to have the child create a short narrative (Berman \& Slobin, 2009). Therefore, another research question to answer is: can the same Roma children create a narrative looking at a series of pictures? We recognize that most of them do not have experiences creating a coherent and cohesive story looking at pictures. Children of this age often produce narratives that are barely describable as such, often being incoherent, and lacking any plot or connecting devices. Before age 5 or so, children are prone to tell stories using what Bruner calls "the landscape of action", in which they simply recount or name the actions that happened. But true stories requite integrating this language of events with the landscape of consciousness: who were the characters, what were their intentions, goals and beliefs? Only older children can do this with some competence. It has been argued that narratives that include such mentalistic themes reflect the children's growing understanding that others have minds, with contents that may be different than their own, i.e. Theory of Mind. In fact, in the case of African American children studied by Curenton (2004), the children showed competence in their narratives even when they were not performing as well as their white peers on standardized tests of Theory of Mind reasoning.

The inclusion of a narrative task with specific questions relating to Theory of Mind was therefore justified on two grounds: one, to offer some convergent validity to the language test, and second, to investigate the relationship between language competence and Theory of Mind, both in the linguistic test and in the narrative itself. Until now in the scientific literature there is no information about the connection between language complexity, narrativity of Roma children and their Theory of Mind. This is a first attempt to give an answer to such a research question. 


\subsection{Design of the Test}

The language test is composed of ten subtests (Table 1). Taking note of recent recommendations in the field of assessment for language, we measured not only what a child knows (language products), but also their ability to learn (language processes) (Hirsh-Pasek, Kochanoff, Newcombe, \& de Villiers, 2005; de Villiers et al., 2014).

Components and modules of Romani test

\begin{tabular}{ccc}
\hline Test type & Subtest & Skill tapped \\
\hline \multirow{2}{*}{ Language Processes } & Possessive & Production \\
& Tense & Production \\
& Aspect & Comprehension \\
& Fast Mapping nouns & Comprehension \\
& Fast Mapping & Comprehension \\
Language Products & adjectives & \\
& Passives & Comprehension \\
& Wh complements & Comprehension \\
& Wh paired questions & Comprehension \\
& Sentence Repetition & Production \\
& Number Repetition & Production
\end{tabular}

As examples of language processes tests, the possessive and tense subtests were based on the "wug" test developed by Jean Berko Gleason (1958). The wug test was designed to see if a child could apply a rule of the language, such as plural morphology, to a new lexical item: "Here is a wug, here is another one, there are two ... (wugs)" using a cloze-test. This research demonstrated how children learn productive rules. For Romani we elicited from the children the possessive forms, which are complex, as the form is contingent both on the gender and number of the subject and object of possession. In the tense subtest, children have to apply the tense to a novel verb.

Here is an example from the Possessive Test. The child is shown a new unknown character. We name him Kobo (a word which does not exist in Romani). We use the new character with the masculine article $o$ which gives the child a signal that the used possessive ending should also be masculine.

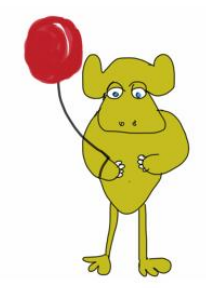

\section{Example:}

Romani: Akava si o Kobo. Si les jekh baloni. Akava nanaj tiro baloni, akava si ...(Kobo-sko baloni) 
[English: This is Kobo. He has a balloon. This is not your balloon, this is ...(Kobo's balloon)]

The Aspect, fast mapping nouns and fast mapping adjective subtests were inspired by research on children's use of a sentence context in word learning (Gleitman, Cassidy, Nappa, Papafragou \& Trueswell 2005). A very sophisticated test of aspect morphology asked the child to pick out which picture depicted an ongoing versus completed novel action, named by a novel verb inflected with that morphology. The fast mapping tests are designed to reveal whether a child can learn new nouns and adjectives by exploiting the morphological cues such as gender in Romani.

Here is an example from the Aspect Test. The child is shown a picture and introduced to an unknown verb in ongoing or completed aspect and the child has to produce the other form when prompted.

\section{Example:}

Romani: Akate i daj sar kerla zumi, i čhaj trampela pe papuske bala.

Akate idaj sar kerla zumi, i chaj... (trampedas) pe papuske bala.

[English: Here, while the mother was cooking the girl was TRAMPELA (X-ing, ongoing) the hair of the grandfather.

Here, while the mother was cooking the girl .......TRAMPEDAS (X-ed, completed action) the hair of the grandfather]

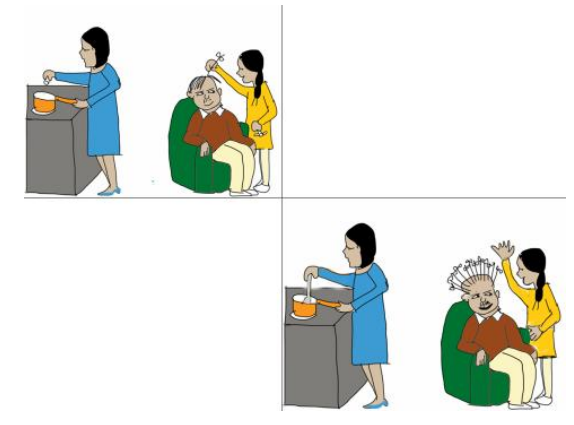

The language product subtests reflect general principles for grammars for children in this age range. Questions prove revealing in many languages (Roeper \& de Villiers 2011; de Villiers, Roeper, Bland-Stewart, \& Pearson 2008), as do passive sentences (Deen, 2011), both of which involve movement of words from their original places in the sentence. The passives subtest was designed to test whether in Romani also, children at younger ages and less ability treat a passive sentence as if it were an active form, reversing the meaning. As in previous research we designed it to test whether children have greater difficulty with passives when the verbs are about states rather than actions, such as "seeing", or "wanting" (Maratsos, Fox, Becker, \& Chalkley, 1985).

For the Wh-complements subtest, embedded sentences are the topic of interest. Children in the preschool years must learn to interpret recursive structures in which one sentence is embedded in another. In this questions subtest, children must remember the content of an embedded clause that differs from what actually happened (de Villiers \& Pyers, 2002). Mastery of these types of clause has been correlated with children's ability at false belief reasoning, or the ability to understand that the contents of 
someone else's thoughts might be different than their own (de Villiers, \& Pyers, 2002; de Villiers, 2005; de Villiers, 2007).

The Wh-questions subtest was chosen because it has been used across many European languages to show whether children have grasped the semantics of grammatical forms (Schulz \& Roeper, 2011). The child is asked a very simple question such as "who ate what?", but the answer requires pairing two sets with one another: the set of subjects must be paired one-to-one with the set of objects to give a complete answer. Here is an Example:

Romani: Kon, so xal?

[English: Who eats what?]

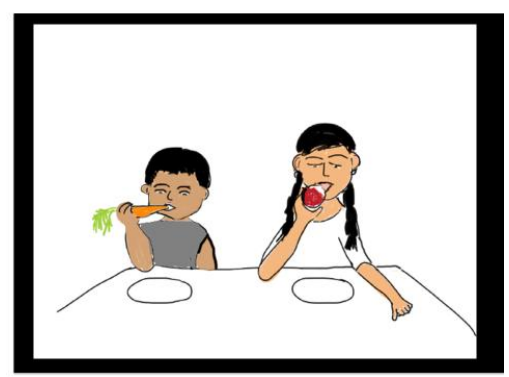

Finally, we have a sentence repetition task in which several sentences that the child must repeat are quite complex. Problems with sentence repetition are reported to be ind icators of language impairment (Conti-Ramsden, Botting, Faragher, 2001; Stokes, Wong, Fletcher \& Leonard, 2006), as children generally can repeat sentences adequately only if they understand them (Lust, Flynn \& Foley, 2006).

Examples:

Romani: Giljabel i Maria ando škola [English: Maria sings at school]

Romani: $O$ dad dikhljas e čhaves thaj dijas les jekh lil. [English: The father saw the boy and gave him a book]

Romani: Palal $i$ škola o čhavo keldas e aver čhavensa futboli [English: After school the boy played football with other children]

\section{Methodology of the study}

\subsection{Participants}

The participants consisted of 29 children from Roma communities in Tetovo and Kumanovo in Macedonia, and 27 children from Roma communities in Kruševac in Serbia. The Roma communities in Macedonia are multilingual. Together with Romani and Macedonian, they also speak Albanian and Turkish. The Roma children who attend kindergarten also learn Albanian together with Macedonian. They belong to two main groups of Roma: Arlija and Kovači in Macedonia. The Roma children in Serbia are bilingual. They speak Romani at home and learn Serbian at kindergarten. Most of the children belong to the Roma group called Timarja, and a small part of the children belong to the Arlija group. The Arlija and Kovački dialects belong to the so-called non-Vlax dialects and the Timarja speak a dialect which belongs to the group of Vlax dialects. 
The communities in both countries are segregated. They live in ghetto types of settlements. Most of the families have access to the internet and they have TV sets in their households, but very few families have books or journals at home. Most of the parents are unemployed and specially the Serbian Roma very often go to work in Austria or in Germany and the children are left with the grandparents. Most of the parents have only basic level education, and very few of them have gymnasium level education.

Some of the children grow up in extended families where two or three generations live together. During different activities parents and family members use different registers and languages in their communication with the children. There are situations where Romani as a mother tongue is used, but there are other situations where the official language of the country is used or other minority languages such as Albanian or Turkish (among Macedonian Roma) are used.

In the next Table 2 we show the number of the children in the study by age group, by gender, and by country.

Table 2

The number of the participants in the study by gender, age and country

\begin{tabular}{ccccc}
\hline Country & \multicolumn{2}{c}{ Macedonia } & \multicolumn{2}{c}{ Serbia } \\
\hline Gender & Boys & Girls & Boys & Girls \\
\hline 3 year olds & 5 & 5 & 5 & 3 \\
4 year olds & 4 & 6 & 5 & 4 \\
5 year olds & 6 & 3 & 5 & 5
\end{tabular}

\subsection{Procedure}

After a parent gave consent for the child's participation, the child's birthdate and gender were recorded. Then each child was tested by a main researcher in the presence of a community member, who helped with the introduction and explanation of the whole procedure.

The test was shown on paper and the answers of the children were written on special paper protocols. Part of the test was tape-recorded for later checking. In some cases, two or three short sessions were allowed to finish the test, particularly with younger children. After the test, the child was shown the two picture sets to elicit narratives. The procedure was as follows.

\section{Narrative}

The children were shown two series of pictures which can be used to develop a narrative. The narratives are roughly modeled after a traditional Theory of Mind task in which an item is moved from its original position and one character does not see that move (Wimmer \& Perner, 1983). The last pictures are used for probe questions to see if the child understands the Theory of Mind question, such as "why is the boy looking there?" One such story was published in the DELV (Seymour et al., 2005), the other was modeled closely on it. The Stimulus Book was set between the researcher and the child. 
The child was then told: "Now I'm going to show you some pictures and ask you to tell me a story. Make sure that you look at all of the pictures before you tell me the story. (The researcher turns the page and pauses). Here is a story. Look carefully at each picture to see what happened. (The researcher pauses then shows the child his page.) I can't see the pictures, so tell me the whole story."

Then the Stimulus Book was repositioned. The researcher pointed to the first picture and said: "Now start at the beginning and tell me the story". When the child is finished, the researcher said: "Is that the whole story?" If the child did not respond, the researcher said: "Remember, I can't see the pictures. Start at the beginning and tell me the story."

The final test administered was a digit span test, as a rough index of nonverbal intelligence. Forward digit span is measured by asking the child to repeat a series of numbers spoken at a steady pace. The test begins with a sample trial and then proceeds to longer and longer strings until the child fails at some level or length of string. In this case two examples were given at each level of length 2 through $N$ until the child failed both examples at one level. The final level at which the child passed both examples was considered the digit span. The digits were chosen to avoid repeated digits and to avoid any string of numbers that might be meaningful. We also took account of the number of syllables for Romani numbers (some are one, some are two syllables) and balanced the test so that the total number of syllables was the same for each member of the pair at a level.

\section{Results}

The first question to be asked when comparing the performance of two different populations is how well matched are they in background measures? There are wellknown dimensions that can have an effect on performance on a language test, and one of them is social class (Hoff , 2013). But that is typically indexed in the West, especially the US, using parental education, because it is argued that it is not wealth or possessions per se that makes a difference, but the quality of child care and language interactions, not to mention opportunities that wealthier children have for enriched experiences. All the children in this study were from homes where parents had a low level of education, and almost all were living in at most, working class communities.

A second known contributor especially to such measures as accumulated vocabulary is the child's intelligence, indexed by a standard IQ test. For this purpose, we used the most culture-fair test we could find, namely digit span, which measures short-term memory for known verbal items. We used a statistical procedure of analysis of variance to compare the two groups of country of residence (Serbia and Macedonia) with age as an additional factor (3, 4, 5 year olds). There were no significant differences by country $(\mathrm{F}(56,1=1.46, \mathrm{p}=.989)$ nor interactions with age. However age as expected was massively significant $(F(56,2)=38.7 \mathrm{p}<.001)$ : the children could remember more digits as they got older.

Given the close matching in socioeconomic status, parent education and digit span performance, it is now possible to compare the children's performance on the Romani tests without fear of confounds. Figure 1 shows the means by country of residence 
averaged across age group. On every subtest the children improve with age in both languages. However on some subtests, country of residence make a significant difference too. Inspection of the means reveals that for the three subtests Passive, Tense, and Possessives, the Serbian Romani speakers outperform the Macedonian Romani speakers. On all other subtests, the two groups behave equivalently.

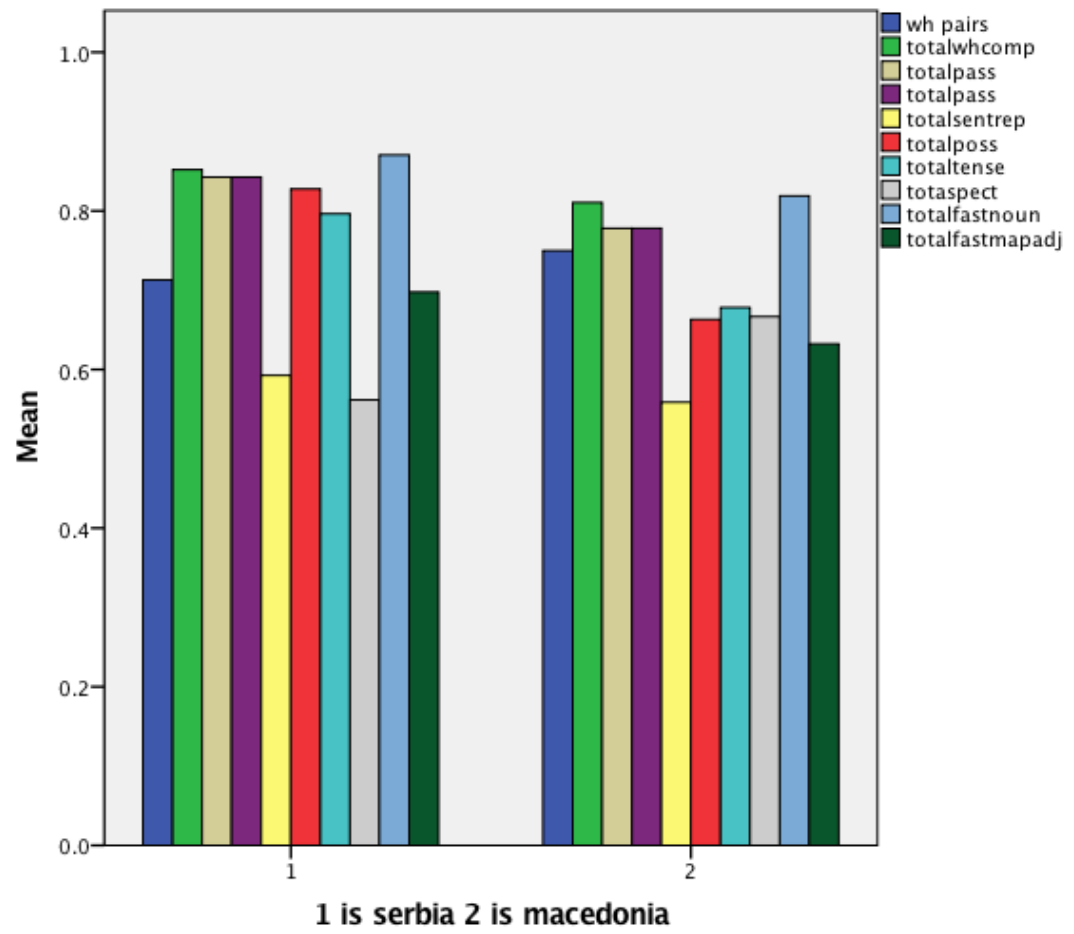

Fig. 1. Performance on the Romani Language Subtests by Country of Residence

If one takes the groups together, the 98 different items on the test have a very high interrelationship, namely Cronbach's alpha. Taken as two separate groups, the Cronbach inter item reliability is also high and equivalent. For each group the test appears to have high internal reliability, that is, the items hang together as measuring a similar trait of language competency. This is a good feature of a test. Fig. 1 illustrates well the findings of the two groups.

The narratives have not yet been fully analyzed, so we cannot yet provide evidence as to the validity of the test from the narrative measure. However, we can look at the questions about Theory of Mind at the end of the two narratives were summed, to give a score out of 4 . If we take this ToM score as the dependent measure, there is an expected effect of age group $(F(56,2)=23.68, p<.001$ in the analys is of variance with country of residence and age group as grouping variables), that is, the children get steadily better at answering the questions by age. However there is also an unexpected effect of country of residence $(F(56,1)=8.15, p<.006)$ in the analysis of variance with country of residence and age group as grouping variables). In contrast to the findings on the language measures, the Macedonian Roma children outperform the Serbian Roma children. The means by age and country are shown in Fig. 2. It is evident that the Serbian Roma children appear to have an early disadvantage at the tasks but they catch up by age 5 to the 
Macedonian Roma children. This interaction by age and country of residence does not quite reach significance.

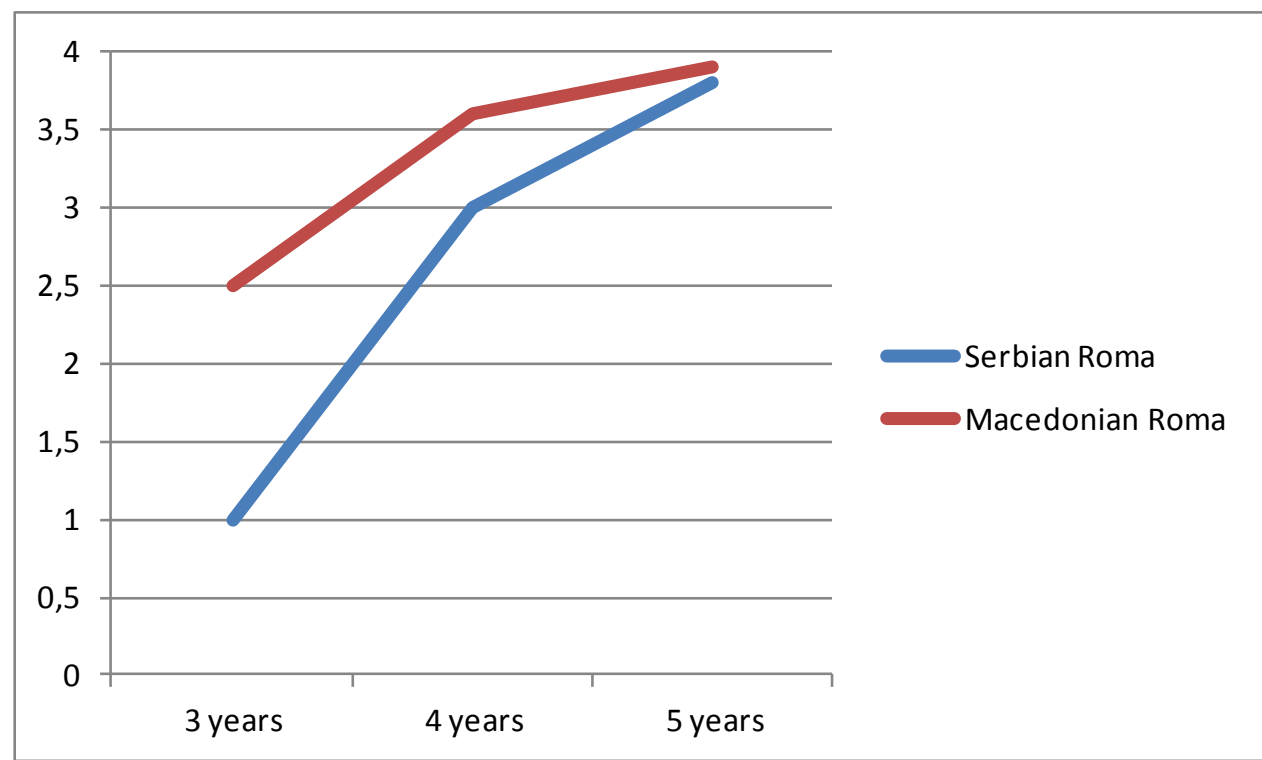

Fig. 2. Performance on the Theory of Mind task across age by country of residence

Furthermore, there is evidence that the better the children do on the language test, the better their performance on the Theory of Mind questions. If we consider all the children together, the correlation (the degree of association) between the language scores and the Theory of Mind scores is very high. Interestingly, it is less high for the Macedonian Roma ( $\mathrm{r}=.570)$ than for the Serbian Roma (=.886), though both are highly significant statistically.

\section{Discussion}

Our goals have been to explain the difficulties that Roma children have in gaining access to a good early education, given the fact that they are often from lower SES backgrounds, often multilingual, and their native language is not only not the State language, but is even regarded as defective. This is an important policy issue emphasized by many official groups in Europe (e.g. ERRC, 2014).

Our research is still underway, but some of the results are striking. At variance with the low regard for the Roma children's intelligence usually held by educational establishments, we draw attention to the children's scores on two well established types of test in early childhood - digit span and Theory of Mind. Their scores are perfectly in line with those of children of their age from many different cultures, including middle class children in the US (Chen \& Stevenson, 1988; Wellman, Cross \& Watson, 2001). The tests of language challenged them to show not only what they know already but also what they could do by extension to learn new things. The children proved proficient in most aspects and with sensible growth curves in the 3 to 6 age range. Despite their impoverished circumstances, these children are good language learners, well launched in their native language.

The differences between the two groups are tantalizing. The Romani-speaking children from the two countries are very well matched in background and digit span. 
Their skills are also fairly similar across the test as a whole, and very close on the tests of process. Three particular subtests stand out as different: Passives, Possessives and Tense. It can be argued that these are challenging in different ways: Passives because they are rare, Possessives because the paradigm is so complex, and Tense perhaps because Romani also marks Aspect. In each of these cases it could be argued that enough input must be present for the child to form the appropriate morphological paradigms, and that with multiple languages in the environment the exposure to enough Romani is compromised. The difference between Serbian and Macedonian Roma children goes along those lines, with Macedonian Roma having demands on them to learn more languages for everyday use than the Serbian children. These particular subtest tap phenomena that may be particularly sensitive to input frequency, and there is good reason to suppose that the Macedonian children need more time to hear enough.

Given the slightly better performance of the Serbian group on the language test, what can we make of the superior performance on Theory of Mind by the Macedonian children? Researchers have previously argued that Theory of Mind may be advantaged by having two languages, just like executive function is (Goetz, 2003; Kovacs, 2009). In particular, these researchers argue that the requirement to assess whether a listener should be addressed in one language or the other attunes the child to other minds, and the switching required of them enhances executive function skills. In this study almost all the children are bilingual, but the Macedonian group may be in an even a richer set of language circumstances. Alternatively, the linguistic skills needed to solve the task may be distributed across their several languages, but we assessed only their Romani. There may be truth in both accounts, but the data are insufficient to settle the matter. The Macedonian Roma children begin at a higher point in Theory of Mind, but the Serbian group catches up by age 5 .

\section{References}

Bakalar, P. (2004). The IQ of Gypsies in Central Europe. The Mankind Quarterly, XLIV, (3\&4), 291-300.

Bedore L.M., Peña E.D., García, M. \& Cortez, C. (2012). Conceptual versus monolingual scoring: when does it make a difference? J Speech Lang Hear Res 55(1), 1-15.

Berko, J. (1958). The Child's Learning of English Morphology. Word 14, 150-177.

Berman, R. \& Slobin, D. (2009). Relating Events in Narrative: A Cross-Linguistic developmental Study, vol. 1. New York and London: Psychology Press.

Bialystok, E. (2001). Bilingualism in development: Language literacy and cognition. Cambridge University Press: Cambridge.

Bialystok, E. \& Craik, F. (2010). Cognitive and Linguistic processing in the bilingual mind. Current Directions in Psychological Science, 19, (1), 19-23.

Bialystok, E., Craik, F., and Freedman, M. (2007). Bilingualism as a protection against the onset of symptoms of dementia. Neuropsychologia, 45, 459-464.

Brucker, J. L. (n.d). A study of Barriers to Educational Attainment in the Former Yugoslav Republic of Macedonia. www.unicef.org/ceecis/Roma_children.pdf

Bruner, J. (1986). Actual mind, possible worlds. Cambrid ge: Harvard University Press.

Carlson, S. \& Meltzoff, A. (2008). Bilingual Experience and Executive Functioning. Bilingualism: Language and Cognition, 6 (1), 1-15. 
Chen, C. \& Stevenson. H. (1988). Cross-Linguistic Differences in Digit Span of Preschool Children. Journal of Experimental Child Psychology 46, 150-158

Conti-Ramsden, S., Botting, N. \& Faragher, B. (2001). Psycholinguistic Marker for specific Language Impairment (SLI). Journal of Language Psychology and Psychiatry, 42 (6), 741-748.

Curenton, S. M. (2004). The association between narratives and theory of mind for low-income preschoolers. Early Education and Development, 15 (2), 120-143.

Deen, Kamil Ud (2011). The Acquisition of the Passive. In de Villiers, J. \& T. Roeper. (eds) Handbook of Generative Approaches to Language Acquisition (pp. 155-188). Amsterdam: John Benjamins Publisher.

de Villiers, J., Pace, A., Yust, P., Takahesu Tabori, A., Hirsh-Pasek, K., Golinkoff, R. M., Iglesias, A., \& Wilson, M.S. (2014). Predictive value of language processes and products for identifying language delays. Poster accepted to the Symposium on Research in Child Language Disorders, Madison, WI.

de Villiers, J. G. (2015). Taking Account of Both Languages in the Assessment of Dual Language Learners. In Iglesias, A. (Ed) Special issue, Seminars in Speech, 36 (2) 120-132.

de Villiers, J. G. (2005). Can language acquisition give children a point of view? In J. Astington \& J. Baird (Eds.), Why Language Matters for Theory of Mind. (pp186-219) New York: Oxford Press.

de Villiers J. G. \& Pyers, J. (2002). Complements to Cognition: A Longitudinal Study of the Relationship between Complex Syntax and False-Belief Understanding. Cognitive Development, 17: 1037-1060.

de Villiers, J. G., Roeper, T., Bland-Stewart, L. \& Pearson, B. (2008). Answering hard questions: wh-movement across dialects and disorder. Applied Psycholinguistics, 29:67-103.

Friedman, E., Gallová Kriglerová, E., Kubánová, M. \& Slosiarik, M. (2009). School as Ghetto: Systemic Overrepresentation of Roma in Special Education in Slovakia. Roma Education Fund.

ERRC (European Roma Rights Center) (1999). A special remedy: Roma and Special schools for the Mentally Handicapped in the Czech Republic. Country Reports Series no. 8 (June)

ERRC (European Roma Rights Centre) (2014). Overcoming barriers: Ensuring that the Roma children are fully engaged and achieving in education. The office for standards in education. online at http://www.errc.org

ERRC (European Roma Rights Centre) (2015). Czech Republic: Eight years after the D.H. jud gment a comprehensive desegregation of schools must take place http://www.errc.org

Fremlova, L. \& Ureche, H. (2011). From Segregation to Inclusion: Roma pupils in the United Kingdom. A Pilot research Project. Budapest: Roma Education Fund.

Gleitman, L., Cassidy, K., Nappa, R., Papafragou, A. \& Trueswell, J. (2005). Hard words. Language Learning and Development, 1, 23-64.

Goetz, P. (2003). The effects of bilingualism on theory of mind development. Bilingualism: Language and Cognition. 6. 1-15.

Hart, B. \& Risley, T.R (1995). Meaningful Differences in the Everyday Experiences of Young American Children. Baltimore, MD: Brookes Publishing

Heath, S. B. (1982). What no Bedtime Story Means: Narrative skills at home and at school. In Language and Society. 11.2:49-76.

Hirsh-Pasek, K., Kochanoff, A., Newcombe, N. \& de Villiers, J.G. (2005). Using scientific knowledge to inform preschool assessment: making the case for empirical validity. Social Policy report (SRCD) Volume XIX, 1, 3-19.

Hirsh-Pasek K., Adamson, I.B., Bakeman, R., Tresch Owen, M., Golinkoff, R.M., Pace, A., Yust, P \& Suma, K. (2015). The Contribution of Early Communication Quality to LowIncome Children's Language Success. Psychological Science Online First, June 5, 2015 doi:10.1177/0956797615581493 
Hoff, E. (2013). Interpreting the early language trajectories of children from low-SES and language minority homes: implications for closing achievement gaps. Developmental Psychology, 49(1):4-14.

Hoff, E. \& Elledge, C. (2006). Bilingualism as One of Many Environmental Variables that Affect Language Development in Young Children. In J. Cohen, K. McAlister \& J. MacSwan (Eds.), Proceedings of the 4th International symposium on Bilingualism (pp. 1034-1040). Somerville, Ma: Cascadilla press.

Hoge, W. (1998). A Swedish Dilemma: The Immigrant Ghetto. The New York Times, October 6th.

Kovacs, A. (2009). Early Bilingualism Enhances Mechanisms of False-Belief Reasoning. Developmental Science, 12 (1), 48-54.

Kyuchukov, H. (2005). Early socialization of Roma children in Bulgaria. In: X. P. RodriguezYanez, A. M. Lorenzo Suarez \& F. Ramallo (Eds.), Bilingualism and Education: From the Family to the School. Muenchen: Lincom Europa. (pp. 161-168)

Kyuchukov, H. (2010) Romani language competence. In: J. Balvin and L. Kwadrants (Eds.), Situation of Roma Minority in Czech, Hungary, Poland and Slovakia (pp. 427-465). Wroclaw: Prom.

Kyuchukov, H. (2014). Acquisition of Romani in a Bilingual Context. Psychology of Language and Communication, vol. 18 (3), 211-225.

Kyuchukov, H. (2013). Romani language education and identity among the Roma children in European context. In: J. Balvin, L. Kwadrans and H. Kyuchukov (eds) Roma in Visegrad Countries: History, Culture, Social Integration, Social work and Education (pp. 465-471). Wroclaw: Prom.

Kyuchukov, H. (2015). Socialization of Roma children through Roma oral culture. In: Socializaciya rastushego cheloveka $v$ kontekste progressyivnyih nauchnich ideii XXI veka: socialnoe razvitie detey doshkolnogo vozrastta. [Socialization of the growing man in the context of progressive ideas of the XXI c.: social development of the preschool age children] Proceedings form the First international All-Russia conference, 1-3 April, Yakutsk, pp. 798-802.

Kyuchukov, H. \& de Villiers, J. (2009). Theory of Mind and Evidentiality in Romani-Bulgarian Bilingual children. Psychology of Language and Communication, 13(2), 21-34.

Kyuchukov, H. \& de Villiers, J. (2014a). Roma children's knowledge on Romani. Journal of Psycholinguistics, 19, 58-65.

Kyuchukov, H. \& de Villiers, J. (2014b). Addressing the rights of Roma children for a language assessment in their native language of Romani. Poster presented at the $35^{\text {th }}$ Annual Symposium on Research in Child Language Disorders in Madison, Wisconsin June 12-14.

Lajčakova, J. (2013). Civil Society Monitoring Report on the Implementation of the National Roma Integration Strategy and Roma Decade Action Plan in 2012 in Slovakia. Budapest: Decade of Roma Inclusion. Secretariat Foundation.

Landry, S. and the School Readiness Research Consortium (2014). Enhancing Early Child Care Quality and Learning for Toddlers at Risk: The Responsive Early Childhood Program. Developmental Psychology, 50 (2), 526-541.

Lust, B., Flynn, S. \& Foley, C. (1996). What Children Know about What They Say: Elicited Imitation as a Research Method for Assessing Children's Syntax. In D. McDaniel, C. McKee, \& H. Smith Cairns (Eds.), Methods for Assessing Children's Syntax (pp. 55-76). Cambridge, Mass.: MIT Press.

Maratsos, M., Fox, D.E.C., Becker, J.A. \& Chalkley, M.A. (1985). Semantic restrictions on children's passives. Cognition, 19, 167-191.

Merz, E.C. Zucker, T.A., Landry, S.H. Williams, J., Assel, M., Taylor, H.B, Lonigan, C.L., Phillips, B., Clancy-Menchetti, J., Barnes, M., Eisenberg, N., de Villiers, J. (2015). 
Parenting predictors of cognitive skills and emotion knowledge in socioeconomically disadvantaged preschoolers. Journal of Experimental Child Psychology 132, 14-31

Pearson, B. Z., Jackson, J. E., \& Wu, H. (2014). Seeking a valid gold standard for an innovative dialect-neutral language test. Journal of Speech-Language and Hearing Research. 57(2). 495-508.

Reger, Z. (1999). Teasing in the linguistic socialization of Gypsy children in Hungary. Acta Linguistica Hungarica, 46, 289-315.

Réger, Z. and Berko-Gleason, J. (1991). Romāni Child-Directed Speech and Children's Language among Gypsies in Hungary Language in Society, 20 (4), 601-617.

Roeper, T \& de Villiers, J.G. (2011). The acquisition path for wh-questions. In de Villiers, J.G. \& Roeper, T. (Eds), Handbook of Generative Approaches to Language Acquisition. Springer.

Seymour, H., Roeper, T. \& de Villiers, J. (2005). The DELV-NR. (Norm-referenced version) The Diagnostic Evaluation of Language Variation. The Psychological Corporation, San Antonio.

Schulz, P. \& Roeper, T. (2011). Acquisition of exhaustively in wh-questions: a semantic dimensions of SLI. Lingua, 121(3), 383-407.

Stokes, S. F., Wong, A. M-Y., Fletcher, P., \& Leonard, L. B. (2006). Nonword repetition and sentence repetition as clinical markers of SLI: The case of Cantonese. Journal of Speech, Language and Hearing Research, 49(2), 219-236.

Vassilev, R. (2004). The Roma of Bulgaria: A Pariah Minority. The Global Review of Ethnopolitics, 3 (2), 40-51.

Wellman, H.M., Cross, D., \& Watson, J. (2001). Meta-analysis of theory-of-mind development: The truth about false belief. Child Development, 72, 655-684.

Wimmer, H., \& Perner, J. (1983). Beliefs about beliefs: Representation and constraining function of wrong beliefs in young children's understanding of deception. Cognition, 13, 103-128. 